\title{
IL-4, IL-10 and TNF- $\alpha$ Polymorphisms in Idiopathic Membranous Nephropathy (IMN)
}

\author{
Mauro Giacomelli1,2*, Rajesh Kumar',2, Giacomo Tampella1,2, Simona Ceffa ${ }^{3}$, \\ Mario Bontempelli ${ }^{3}$ \\ ${ }^{1}$ Institute of Molecular Medicine "Angelo Nocivelli", University of Brescia, Brescia, Italy \\ ${ }^{2}$ Scuola di Dottorato in Scienze della Riproduzione e dello Sviluppo, University of Trieste, Trieste, Italy \\ ${ }^{3}$ Immunology Laboratory, Ospedali Riuniti of Bergamo, Bergamo, Italy \\ Email: "mauro.giacomelli@unibs.it
}

Received 25 October 2015; accepted 28 November 2015; published 3 December 2015

Copyright (C) 2015 by authors and Scientific Research Publishing Inc.

This work is licensed under the Creative Commons Attribution International License (CC BY).

http://creativecommons.org/licenses/by/4.0/

(c) () O Open Access

\begin{abstract}
Idiopathic membranous nephropathy (IMN) is a Th2 nephritogenic immune disorder. It is caused by the accumulation of immune complexes, mainly IgG4, at the basal glomerular membrane that leads to the damage of the glomerular barrier and subsequent injury of podocytes. Our aim was to evaluate the relationship between cytokine polymorphisms and IMN. We investigated the cytokine polymorphisms in forty-five patients and one hundred twenty-four healthy individuals, using polymerase chain reaction-sequence specific primers (PCR-SSP). We showed a significant increase in allelic frequencies of the alleles -590T and -33T of IL-4 gene and -308A of TNF- $\alpha$ gene, in IMN patients. In addition, we observed an increased frequency of allele -1082G in IL-10 gene in a subgroup of patients with CD4/CD8 ratio major than 2, when compared either to control subjects or the subgroup of patients with CD4/CD8 ratio minor than 2. Moreover, analyzing the Th1/Th2 cytokines in serum and urine, we found increased levels of IL-4 in serum and IL-5 in urine of patients. We deduce that the alleles -590T and -33T of IL-4 and -308A of TNF- $\alpha$ may be associated with IMN. In addition, in patients with increased T helper lymphocytes, IL-10 -1082G polymorphism can also play a role in the pathogenesis of the disease. These findings remark the role of Th2 immune response and suggest the association between polymorphic variants of IL-4, IL-10 and TNF- $\alpha$ genes with the development of IMN and therefore giving a better insight in pathogenesis of this disease.
\end{abstract}

\section{Keywords}

Interleukin-Four, Tumor Necrosis Factor- $\alpha$, Interleukin-Ten, Idiopathic Membranous Nephropathy, Immunoglobulin G Sub-Class 4

\footnotetext{
${ }^{*}$ Corresponding author.
}

How to cite this paper: Giacomelli, M., Kumar, R., Tampella, G., Ceffa, S. and Bontempelli, M. (2015) IL-4, IL-10 and TNF- $\alpha$ Polymorphisms in Idiopathic Membranous Nephropathy (IMN). Open Journal of Immunology, 5, 233-243. 


\section{Introduction}

Idiopathic membranous nephropathy (IMN) is a rare immune disease and also the most common cause of nephrotic syndrome in adults. It is caused by the accumulation of immune complexes in the basal glomerular membrane, which in turn damages the podocytes through complement-dependent processes. The major role of podocytes is to synthesize the components of glomerular filtration barrier [1]. The damaged podocytes cause a decrease in the filtration capacity of the glomerulus, resulting in marked proteinuria. The immune complexes deposited in the subepithelial glomerulus in IMN patients are mainly IgG4 [2]-[4].

IgG4 is a subclass of antibodies that is produced in response to prolonged and recurrent antigenic stimulations [5], or to helminthic infections [6]. These antibodies are monovalent and have low avidity. IgG4 antibodies are unable to bind the complement, but they form small non-precipitating complexes [7] [8]. The serum levels of these antibodies are often increased in subjects affected by IMN [2] [3].

IMN is a Th2 nephritogenic immune disorder. T helper lymphocytes, which are often increased in these patients, produce significantly more IL-4 [9], whereas B lymphocytes generate more IgG4, than healthy individuals, when cultured in presence of IL-4 [10]. IL-4 is a major Th2 cytokine that induces the isotype switching towards IgG4 and IgE, this induction is potentiated by IL-10, another Th2 cytokine [11]-[13].

The polymorphisms of IL-4 and IL-13 are already associated to the minimal change nephrotic syndrome (MCNS), a disorder of pediatric age characterized by an increase in IgE levels [14]. Moreover, genetic variants of STAT6, which transduces the signal through the IL-4 receptor alpha (IL-4Ralpha), are also linked to MCNS's clinical course [15]. Nevertheless, a direct correlation between IL-4 polymorphisms and IMN was never established.

Some authors indicated that the impaired immune response in IMN could be also related to the B cell compartment. In fact, there are also large infiltrates of B CD20 positive lymphocytes in tubule-interstitial compartment [16]. The role of these B cells in pathogenesis of the IMN is still unknown. B cells probably act as antigen presenting cells (APCs) rather than antibody producing cells. In fact Rituximab, an anti-CD20 antibody, is currently used in the treatment of the Membranous Nephropathy [17] [18].

The cytokines are key factors in modulating the immune response and class switching of antibodies. Cytokines modulate the activity of $\mathrm{T}$ and $\mathrm{B}$ lymphocytes, regulate cellular activities and the response to pathogens. The polymorphisms in promoter regions of cytokine genes can influence the transcriptional and expression levels of these cytokines [19]-[23].

Many research groups have established the link between these polymorphisms and various pathologies. For instance, the variant -572C of IL-6 gene and the polymorphism -308A of TNF- $\alpha$ and TNF d2 allele were associated to IMN in different ethnic groups [24] [25]. Moreover, it is demonstrated that TNF- $\alpha$-308A can also cause Non Idiopathic Membranous Nephropathy [26].

In this study we evaluated the association between polymorphisms in cytokine genes and IMN. We also evaluated the amount of Th1/Th2 cytokines in the serum and the urine collected before the therapeutic treatment. Finally, on the basis of the ratio of CD4/CD8 T lymphocytes, we analyzed whether there were differences in the frequencies of polymorphisms between patients and control group.

\section{Materials and Methods}

\subsection{Subjects}

For this study, one hundred twenty-four controls (Bone marrow donors), aged between 27 and 52 years (mean age 43.5; 70 male and 54 female) [27] and forty-five IMN patients, aged between 21 and 77 years (mean age 51.3; 26 male and 19 female) were enrolled.

Samples were collected at the Department of Nephrology and Immunology of Ospedali Riuniti of Bergamo, between October 2002 and May 2008. Physical examination, hematochemical and urine analysis, $24 \mathrm{~h}$ urinary collection, albumin, creatinine and cholesterol levels, $24 \mathrm{~h}$ creatinine clearance and daily urinary protein excretion have defined the diagnosis of membranous nephropathy (MN). The diagnosis was confirmed on renal biopsies with microscopic and immunofluorescence techniques. Clinical examination and laboratory data excluded the presence of other alterations that could define secondary membranous nephropathies. In fact these patients were negative for tumors, systemic lupus, viral hepatitis infections or other causes of MN like rheumatoid arthritis. These patients were negative for ANA (antinucleus antibodies), RF (Rheumatoid factor), Hepatitis B and Hepatitis C markers (HBsAg and anti-HCV). 
Twenty-four healthy subjects were analyzed for cytokines levels evaluation in serum and urine. Informed consent was obtained from each participant, and the local ethics committee approved the present study.

\subsection{Single Nucleotide Polymorphism Analysis by PCR-SSP (Sequence Specific Primers)}

DNA was extracted from $300 \mu \mathrm{l}$ of peripheral blood by automatic extractor GenoM ${ }^{\mathrm{TM}}$-6 Robotic Workstation (Qiagen). The polymorphism typing was defined by Heidelberg cytokine gene polymorphisms SSP kit (Protrans medizinische diagnotiche produkte, Hockenheim, Germany).

The following polymorphisms were analysed: IL-1 $\alpha$ (T/C -889), IL-1 $\beta$ (C/T -511, T/C +3962), IL-12 (C/A -1188), IFN- $\gamma$ (A/T UTR 5644), TGF- $\beta$ (C/T codon 10, G/C codon 25$)$, TNF- $\alpha$ (G/A -308, G/A -238), IL-2 (T/G -330, G/T +166), IL-4 (T/G -1098, T/C -590, T/C -33), IL-6 (G/C -174, G/A nt 565), IL-10 (G/A -1082, C/T -819, C/A -592), IL-1R (C/T pst 11,970), IL-1RA (T/C mspa 111,100) and IL-4R $\alpha$ (G/A +1902).

PCR reaction was performed using Ampli Taq DNA polymerase $5 \mathrm{U} / \mu \mathrm{l}$, (Applied Biosystems) in GeneAmp PCR System 9700 thermal cycler (Perkin Elmer) using following protocol: initial denaturation at $94^{\circ} \mathrm{C}$ for 2 minutes; denaturation at $94^{\circ} \mathrm{C}$ for 15 seconds; annealing and extension at $65^{\circ} \mathrm{C}$ for 1 minute $(10$ cycles), denaturation at $94^{\circ} \mathrm{C}$ for 15 seconds; annealing at $61^{\circ} \mathrm{C}$ for 50 seconds; extension at $72^{\circ} \mathrm{C}$ for 30 seconds (20 cycles).

Amplicons were visualized by electrophoresis on $2 \%$ agarose gel containing ethidium bromide $0.625 \mathrm{mg} / \mathrm{ml}$.

\subsection{Measurement of Cytokine Levels in Serum and Urine.}

The levels of IL-4, IL-5, IL-10, TNF- $\alpha$ and IFN- $\gamma$ were evaluated by ELISA (Bender MedSystems) with detection limit of 1, <2, 1, 2.5 and $1 \mathrm{pg} / \mathrm{ml}$ respectively. All samples were read in triplicate with an ELISA plate reader, Gralis-Microplate-Reader (Spa Laboratory Bouty). Serum and urine samples were collected before diagnosis and frozen at $-80^{\circ} \mathrm{C}$ until the analysis.

\subsection{Flow Cytometry Analysis of Lymphocyte Subpopulations}

Blood samples from patients were collected at the time of diagnosis and lymphocyte subpopulations were evaluated using FACSCalibur ${ }^{\mathrm{TM}}$ cytometer (Becton Dickinson). Whole blood was stained with the following antibodies: anti-CD3/CD4/CD8/CD45 and anti-CD3/CD19/CD16 + 56/CD45 (Becton Dickinson). All flow cytometric data were analyzed by FlowJo software 7.5. (TreeStar Inc.).

\subsection{Statistical Analysis}

The association between allelic or genotype frequencies and IMN was calculated through contingency tables $2 \times$ 2 and $2 \times 3$ respectively, calculating $\chi^{2}$ test. Cytokine levels, CD4/CD8 ratio comparison and protein daily excretion were analyzed by variance analysis and subsequent execution of the Bonferroni test. A $p$-value less than 0.05 was considered statistically significant.

\section{Results}

\subsection{Allelic and Genotype Frequency of IL-4, IL-10 and TNF- $\alpha$ in IMN Patients}

1) Allele frequency:

The allele frequencies for IL-4 -590T and -33T, were increased in patients when compared to healthy controls $\left(p<1 \times 10^{-6}, p<1 \times 10^{-6}\right.$ respectively). The distribution of TNF- $\alpha-308$ A allele was also statistically different between the two groups ( $p=0.0001$ ), (Table 1$)$. Whereas, for IL-10, the allele $-1082 \mathrm{G}$ didn't show any differences in the two groups analyzed $(p=0.14)$, while the allele -819C was slightly increased in patients $(p=0.046)$, (Table 1).

Other analyzed polymorphisms didn't show any significant differences in the two groups (data not shown).

2) Genotype frequency

The genotype distribution was significantly different for IL-4 T-590C, IL-4 T-33C, TNF- $\alpha$ G-308A and IL-10 G-1082A (Table 2) among the two groups. For IL-4 T-590C, genotypes TT, TC and CC were respectively $13.3 \%, 60 \%$ and $26.7 \%$ in patients vs. $2.4 \%, 9.6 \%$ and $88 \%$ in control subjects $\left(p<1 \times 10^{-6}\right)$. For IL-4 T-33C the genotypes TT, TC, and CC were respectively $4.4 \%, 57.8 \%$ and $37.8 \%$ in patients vs. $2.5 \%, 15.3 \%$ and $82.2 \%$ in control subjects $\left(p<1 \times 10^{-6}\right)$. 
Table 1. The allele frequencies for cytokine polymorphisms in IMN patients respect to healthy controls.

\begin{tabular}{|c|c|c|c|c|c|}
\hline & & \multirow{2}{*}{$\begin{array}{c}\text { Ctrls (n = 248) } \\
\%(n)\end{array}$} & \multirow{2}{*}{$\begin{array}{c}\text { IMN Pts }(\mathrm{n}=90) \\
\% \text { (n) }\end{array}$} & \multicolumn{2}{|c|}{ IMN Pts vs Ctrls } \\
\hline & & & & $\chi^{2}$ & $p$ Value \\
\hline$-590 T$ & \multirow{2}{*}{ IL-4 } & $7.3(18)$ & $42.2(38)$ & \multirow{2}{*}{$\chi^{2}=55.899$} & \multirow{2}{*}{$p<1 \times 10^{-}$} \\
\hline$-590 C$ & & 92.7 (230) & $57.8(52)$ & & \\
\hline$-33 T$ & \multirow{2}{*}{ IL-4 } & $10(25)$ & $33.3(30)$ & \multirow{2}{*}{$\chi^{2}=24.528$} & \multirow{2}{*}{$p<1 \times 10^{-6}$} \\
\hline$-33 C$ & & 90 (223) & $66.7(60)$ & & \\
\hline$-1082 G$ & \multirow[b]{2}{*}{ IL-10 } & $39(97)$ & $49(44)$ & \multirow[b]{2}{*}{$\chi^{2}=2.209$} & \multirow[b]{2}{*}{$p=0.1371$} \\
\hline$-1082 A$ & & $61(151)$ & $51(46)$ & & \\
\hline$-819 C$ & \multirow{2}{*}{ IL-10 } & 68 (169) & $80(72)$ & \multirow{2}{*}{$\chi^{2}=3.975$} & \multirow{2}{*}{$p=0.0461$} \\
\hline$-819 T$ & & $32(79)$ & $20(18)$ & & \\
\hline$-308 A$ & \multirow[b]{2}{*}{ TNF- $\alpha$} & $8(20)$ & $24.4(22)$ & \multirow{2}{*}{$\chi^{2}=14.811$} & \multirow{2}{*}{$p=0.0001$} \\
\hline$-308 G$ & & $92(228)$ & $75.6(68)$ & & \\
\hline
\end{tabular}

Table 2. The genotype frequencies for cytokine polymorphisms in IMN patients respect to healthy controls.

\begin{tabular}{|c|c|c|c|c|c|}
\hline & & \multirow{2}{*}{$\begin{array}{c}\text { Ctrls (n = 124) } \\
\text { \% (n) }\end{array}$} & \multirow{2}{*}{$\begin{array}{c}\text { IMN Pts (n = 45) } \\
\% \text { (n) }\end{array}$} & \multicolumn{2}{|c|}{ IMN Pts vs Ctrls } \\
\hline & & & & $\chi^{2}$ & $p$ Value \\
\hline $\begin{array}{c}\text { IL-4 } \\
\text { T-590C }\end{array}$ & $\begin{array}{l}\text { TT } \\
\text { TC } \\
\text { CC }\end{array}$ & $\begin{array}{c}2.4(3) \\
9.6(12) \\
88(109)\end{array}$ & $\begin{array}{c}13.3(6) \\
60(27) \\
26.7(12)\end{array}$ & $\chi^{2}=60.910$ & $p<1 \times 10^{-6}$ \\
\hline $\begin{array}{c}\text { IL-4 } \\
\text { T-33C }\end{array}$ & $\begin{array}{l}\text { TT } \\
\text { TC } \\
\text { CC }\end{array}$ & $\begin{array}{c}2.5(3) \\
15.3(19) \\
82.2(102)\end{array}$ & $\begin{array}{c}4.4(2) \\
57.8(26) \\
37.8(17)\end{array}$ & $\chi^{2}=32.085$ & $p<1 \times 10^{-6}$ \\
\hline $\begin{array}{c}\text { IL-10 } \\
\text { G-1082A }\end{array}$ & $\begin{array}{l}\text { GG } \\
\text { GA } \\
\text { AA }\end{array}$ & $\begin{array}{c}9.7(12) \\
58.8(73) \\
31.5(39)\end{array}$ & $\begin{array}{l}31.1(14) \\
35.6(16) \\
33.3(15)\end{array}$ & $\chi^{2}=13.304$ & $p=0.0013$ \\
\hline $\begin{array}{c}\text { IL-10 } \\
\text { C-819T }\end{array}$ & $\begin{array}{l}\text { CC } \\
\text { CT } \\
\text { TT }\end{array}$ & $\begin{array}{c}48.5(60) \\
39.5(49) \\
12(15)\end{array}$ & $\begin{array}{c}64.5(29) \\
33.3(15) \\
2.2(1)\end{array}$ & $\chi^{2}=5.350$ & $p=0.069$ \\
\hline $\begin{array}{l}\text { TNF- } \alpha \\
\text { G-308A }\end{array}$ & $\begin{array}{l}\text { AA } \\
\text { GA } \\
\text { GG }\end{array}$ & $\begin{array}{c}3.3(4) \\
9.7(12) \\
87(108)\end{array}$ & $\begin{array}{c}6.7(3) \\
35.5(16) \\
57.8(26)\end{array}$ & $\chi^{2}=17.869$ & $p=0.0001$ \\
\hline
\end{tabular}

Furthermore, for TNF- $\alpha$ G-308A, the genotypes AA, GA, and GG were present respectively in 6.7\%, 35.5\% and $57.8 \%$ of patients, compared to $3.3 \%, 9.7 \%$ and $87 \%$ of healthy subjects, $(p=0.0001)$. Finally, for IL-10, the genotypes GG, GA, and AA of G-1082A were respectively found in 31.1\%, 35.6\% and 33.6\% of patients vs. $9.7 \%, 58.8 \%$ and $31.5 \%$ of healthy controls $(p=0.001)$. We did not find any significant differences in genotypes CC, CT, and TT for IL-10 C-819T, (Table 2).

\subsection{CD4/CD8 Ratio in IMN Patients}

The CD4/CD8 ratio is often increased in IMN, which likely represents a distinctive tract of the altered immune response associated to the pathogenesis of the disease [10] [28]-[31]. Hence, we calculated the CD4/CD8 ratio in 25 control subjects and $45 \mathrm{IMN}$ patients. In control group the ratio was $1.54+/-0.23$ whereas in IMN patients we identified two different subgroups, one with CD4/CD8 ratio greater than two $(2.87+/-0.83, \mathrm{n}=24)$ and another subgroup with ratio less than two $(1.51+/-0.3, \mathrm{n}=21)$. We did not find healthy controls with CD4/ CD8 ratio greater than two. The differences between the subgroup of patients with CD4/CD8 ratio > 2 was statistically significant when compared either to control subjects $(1.54+/-0.23$ vs. $2.87+/-0.83, p<0.001)$ or the 
subgroup of patients with CD4/CD8 ratio $<2(2.87+/-0.83$ vs. $1.51+/-0.3, p<0.001)$. On the other hand there was no statistical difference observed when the subgroup of patients with CD4/CD8 ratio $<2$ was matched to control subjects $(1.54+/-0.23$ vs. $1.51+/-0.3, p=0.15)$.

\subsection{Allelic and Genotype Frequency of IL-10 in IMN Patients with Increased CD4/CD8 Ratio}

In order to better investigate the meaning of CD4/CD8 ratio in IMN patients, we assessed it in relationship with cytokine polymorphism frequencies.

Our results showed that the variants G-1082A and C-819T for IL-10 is statistically increased in patients with CD4/CD8 ratio $>2$ respect to healthy subjects ( $p=0.005$ and $p=0.011$, respectively), (Table 3 ).

We also compared the group of patients with ratio CD4/CD8 $>2$ to the group of patients with CD4/CD8 ratio < 2, for the same alleles.

The allele frequency for IL-10 -1082G was increased in group with CD4/CD8 $>2(p=0.011)$, while there were no differences for $-819 \mathrm{C}$ allele in the two subgroups of patients $(p=0.102)$, (Table 3$)$.

The genotype frequency was also different between the subgroup of patients with CD4/CD8 ratio $>2$ and healthy controls group. For IL-10 G-1082A, the genotype frequency of GG, GA, and AA was $37.5 \%$, $50 \%$ and $12.5 \%$ in patients, while the frequency was $9.7 \%, 58.8 \%$ and $31.5 \%$ in healthy controls $(p=0.001)$. For IL-10 C-819T, the genotype frequency of CC, CT, and TT was $75 \%, 25 \%$ and $0 \%$ in patients, while the frequency was $48.5 \%, 39.5 \%$ and $12 \%$ in healthy controls $(p=0.034$ ), (Table 4 ).

Finally, we also compared the genotypes among the two subgroups of patients according to the CD4/CD8 ratio. The genotype frequency of GG, GA, and AA for IL-10 G-1082A was significantly different in two groups; $37.5 \%, 50 \%$ and $12.5 \%$ in CD4/CD8 > 2 subgroup and 23.8\%, 19\%, and 57.2\% in CD4/CD8 < 2 subgroup, respectively $(p=0.006)$, (Table 4$)$.

\subsection{Cytokines Levels in Serum and Urine}

We investigated cytokine levels in serum of both patients and healthy controls. The results showed only one significantly altered cytokine, i.e. IL-4. Its levels were $55.40+/-72.41 \mathrm{pg} / \mathrm{ml}$ in patients vs. $0.20+/-0.98 \mathrm{pg} / \mathrm{ml}$ in healthy controls $(p=0.001)$, (Table 5).

Furthermore, cytokine levels in urine were altered for two cytokines. For IL-5 were $5.59+/-7.51 \mathrm{pg} / \mathrm{ml}$ vs. $0.00+/-0.00 \mathrm{pg} / \mathrm{ml}(p=0.001)$; while IL-10 levels were $1.22+/-1.66 \mathrm{pg} / \mathrm{ml}$ vs. $0.00+/-0.00 \mathrm{pg} / \mathrm{ml}(p=$ 0.001), in patients and healthy control subjects, respectively, (Table 6).

Finally, the comparison between the subgroup of patients with ratio CD4/CD8 $>2$ vs. CD4/CD8 $<2$ subgroup, showed a significant difference for IL-10, in urine. Ten patients with ratio CD4/CD8 > 2, compared to eight pa-

Table 3. The allele frequencies for cytokine polymorphisms in IMN patients with ratio CD4/CD8 $>2$ respect to healthy controls and respect to IMN patients with ratio CD4/CD8 $<2$.

\begin{tabular}{|c|c|c|c|c|c|c|c|c|}
\hline & & \multirow{2}{*}{$\begin{array}{c}\begin{array}{c}\text { Ctrls } \\
(n=248)\end{array} \\
\%(n)\end{array}$} & \multirow{2}{*}{$\begin{array}{c}\text { IMN Pts } \\
\begin{array}{c}\text { (CD4/CD8 }>2) \\
(n=48)\end{array} \\
\%(n)\end{array}$} & \multirow{2}{*}{$\begin{array}{c}\text { IMN Pts } \\
\begin{array}{c}(\mathrm{CD} 4 / \mathrm{CD} 8<2) \\
(\mathrm{n}=42)\end{array} \\
\% \text { (n) }\end{array}$} & \multicolumn{2}{|c|}{$\begin{array}{c}\text { IMN Pts }(\text { CD4/CD8 > 2) vs } \\
\text { Ctrls }\end{array}$} & \multicolumn{2}{|c|}{$\begin{array}{l}\text { IMN Pts }(\text { CD4/CD8 > 2) vs } \\
\text { IMN Pts }(\text { CD4/CD8 < 2) }\end{array}$} \\
\hline & & & & & $\chi^{2}$ & $P$ value & $\chi^{2}$ & $p$ Value \\
\hline $\begin{array}{l}-590 \mathrm{~T} \\
-590 \mathrm{C}\end{array}$ & IL-4 & $\begin{array}{c}7.3(18) \\
92.7(230)\end{array}$ & $\begin{array}{l}43.8(21) \\
56.2(27)\end{array}$ & $\begin{array}{l}42.8(18) \\
57.2(24)\end{array}$ & $\chi^{2}=43.678$ & $p<1 \times 10^{-6}$ & $\chi^{2}=0.0163$ & $p=0.898$ \\
\hline $\begin{array}{l}-33 T \\
-33 C\end{array}$ & IL-4 & $\begin{array}{c}10(25) \\
90(223)\end{array}$ & $\begin{array}{l}35.4(17) \\
64.6(31)\end{array}$ & $\begin{array}{l}31(13) \\
69(29)\end{array}$ & $\chi^{2}=19.172$ & $p=1.18 \times 10^{-5}$ & $\chi^{2}=0.0502$ & $p=0.822$ \\
\hline $\begin{array}{l}-1082 G \\
-1082 A\end{array}$ & IL-10 & 39 (97) & $62.5(30)$ & $33.3(14)$ & $\chi^{2}=8.050$ & $p=0.0045$ & $\chi^{2}=6.503$ & $p=0.011$ \\
\hline $\begin{array}{l}-819 C \\
-819 T\end{array}$ & IL-10 & $\begin{array}{l}68(169) \\
32(79)\end{array}$ & $\begin{array}{l}87.5(42) \\
12.5(6)\end{array}$ & $\begin{array}{l}71.4(30) \\
28.6(12)\end{array}$ & $\chi^{2}=6.445$ & $p=0.0111$ & $\chi^{2}=2.681$ & $p=0.102$ \\
\hline $\begin{array}{l}-308 A \\
-308 G\end{array}$ & TNF- $\alpha$ & $\begin{array}{c}8(20) \\
92(228)\end{array}$ & $\begin{array}{l}29(14) \\
71(34)\end{array}$ & $\begin{array}{c}19(8) \\
81(34)\end{array}$ & $\chi^{2}=15.599$ & $p=7.79 \times 10^{-5}$ & $\chi^{2}=0.754$ & $p=0.385$ \\
\hline
\end{tabular}


Table 4. The genotype frequencies for cytokine polymorphisms in IMN patients with ratio CD4/CD8 > 2 respect to healthy controls and respect to IMN patients with ratio CD4/CD8 $<2$.

\begin{tabular}{|c|c|c|c|c|c|c|c|c|}
\hline & & \multirow{2}{*}{$\begin{array}{c}\begin{array}{c}\text { Ctrls } \\
(n=124)\end{array} \\
\% \text { (n) }\end{array}$} & \multirow{2}{*}{$\begin{array}{c}\text { IMN Pts } \\
(\text { CD4/CD8 > 2) } \\
(n=24) \\
\%(n)\end{array}$} & \multirow{2}{*}{$\begin{array}{c}\text { IMN Pts } \\
\left(\begin{array}{c}\text { CD4/CD8 < 2) } \\
(n=21)\end{array}\right. \\
\%(n)\end{array}$} & \multicolumn{2}{|c|}{$\begin{array}{c}\text { IMN Pts (CD4/CD8 > 2) } \\
\text { vs } \\
\text { Ctrls }\end{array}$} & \multicolumn{2}{|c|}{$\begin{array}{c}\text { IMN Pts }(\text { CD4/CD8 }>2) \\
\text { vs } \\
\text { IMN Pts }(\text { CD4/CD8 }<2)\end{array}$} \\
\hline & & & & & $\chi^{2}$ & $P$ value & $\chi^{2}$ & $P$ Value \\
\hline $\begin{array}{c}\text { IL4 } \\
\text { T-590C }\end{array}$ & $\begin{array}{l}\text { TT } \\
\text { TC } \\
\text { CC }\end{array}$ & $\begin{array}{l}2.4(3) \\
9.6(12) \\
88(109)\end{array}$ & $\begin{array}{c}16.7(4) \\
54.2(13) \\
29.1(7)\end{array}$ & $\begin{array}{c}9.5(2) \\
66.7(14) \\
23.8(5)\end{array}$ & $\chi^{2}=41.042$ & $p<1 \times 10^{-6}$ & $\chi^{2}=0.840$ & $p=0.656$ \\
\hline $\begin{array}{c}\text { IL4 } \\
\text { T-33C }\end{array}$ & $\begin{array}{l}\text { TT } \\
\text { TC } \\
\text { CC }\end{array}$ & $\begin{array}{c}2.5(3) \\
15.3(19) \\
82.2(102)\end{array}$ & $\begin{array}{c}4.2(1) \\
62.5(15) \\
33.3(8)\end{array}$ & $\begin{array}{c}4.8(1) \\
52.4(11) \\
42.8(9)\end{array}$ & $\chi^{2}=26.184$ & $p=2.1 \times 10^{-6}$ & $\chi^{2}=0.476$ & $p=0.788$ \\
\hline $\begin{array}{c}\text { IL-10 } \\
\text { G-1082A }\end{array}$ & $\begin{array}{l}\text { GG } \\
\text { GA } \\
\text { AA }\end{array}$ & $\begin{array}{l}9.7(12) \\
58.8(73) \\
31.5(39)\end{array}$ & $\begin{array}{l}37.5(9) \\
50(12) \\
12.5(3)\end{array}$ & $\begin{array}{c}23.8(5) \\
19(4) \\
57.2(12)\end{array}$ & $\chi^{2}=13.790$ & $p=0.0010$ & $\chi^{2}=10.389$ & $p=0.006$ \\
\hline $\begin{array}{l}\text { IL-10 } \\
\text { C-819T }\end{array}$ & $\begin{array}{l}\text { CC } \\
\text { CT } \\
\text { TT }\end{array}$ & $\begin{array}{c}48.5(60) \\
39.5(49) \\
12(15)\end{array}$ & $\begin{array}{l}75(18) \\
25(6) \\
0(0)\end{array}$ & $\begin{array}{c}52.4(11) \\
42.8(9) \\
4.8(1)\end{array}$ & $\chi^{2}=6.746$ & $p=0.0343$ & $\chi^{2}=3.103$ & $p=0.212$ \\
\hline $\begin{array}{l}\text { TNF- } \alpha \\
\text { G-308A }\end{array}$ & $\begin{array}{l}\text { AA } \\
\text { GA } \\
\text { GG }\end{array}$ & $\begin{array}{l}3.3(4) \\
9.7(12) \\
87(108)\end{array}$ & $\begin{array}{c}4.2(1) \\
50(12) \\
45.8(11)\end{array}$ & $\begin{array}{c}9.5(2) \\
19(4) \\
71.5(15)\end{array}$ & $\chi^{2}=24.472$ & $p=5.1 \times 10^{-6}$ & $\chi^{2}=4.769$ & $p=0.092$ \\
\hline
\end{tabular}

Table 5. Th1/Th2 cytokine levels in serum.

\begin{tabular}{|c|c|c|c|c|}
\hline & \multicolumn{4}{|c|}{ Serum } \\
\hline & $\begin{array}{c}\text { Ctrls }(\mathrm{n}=24) \\
(\text { Mean }+/- \text { sd) pg/ml }\end{array}$ & $\begin{array}{c}\text { IMN Pts }(n=24) \\
(\text { Mean }+/- \text { sd) pg/ml }\end{array}$ & $p$ Value & $\begin{array}{c}\text { Detection } \\
\text { Limit pg/ml }\end{array}$ \\
\hline IL-4 & $0.20+/-0.98$ & $55.40+/-72.41$ & $p=0.001$ & 1 \\
\hline IL-5 & $0.00+/-0.00$ & $0.94+/-3.01$ & $p=0.142$ & $<2$ \\
\hline IL-10 & $0.00+/-0.00$ & $1.95+/-5.86$ & $p=0.116$ & 1 \\
\hline TNF- $\alpha$ & $0.00+/-0.00$ & $1.06+/-3.13$ & $p=0.109$ & 2.5 \\
\hline IFN- $\gamma$ & $0.05+/-0.16$ & $0.52+/-0.65$ & $p=0.001$ & 1 \\
\hline
\end{tabular}

Table 6. Th1/Th2 cytokine levels in urine.

\begin{tabular}{|c|c|c|c|c|}
\hline & \multicolumn{4}{|c|}{ Urine } \\
\hline & $\begin{array}{c}\text { Ctrls }(\mathrm{n}=22) \\
(\text { Mean }+/- \text { sd) pg/ml }\end{array}$ & $\begin{array}{c}\text { IMN Pts }(\mathrm{n}=18) \\
(\text { Mean }+/- \text { sd) } \mathrm{pg} / \mathrm{ml}\end{array}$ & $p$ Value & $\begin{array}{c}\text { Detection } \\
\text { Limit pg/ml }\end{array}$ \\
\hline IL-4 & $0.00+/-0.00$ & $9.63+/-40.55$ & $p=0.271$ & 1 \\
\hline IL-5 & $0.00+/-0.00$ & $5.59+/-7.51$ & $p=0.001$ & $<2$ \\
\hline IL-10 & $0.00+/-0.00$ & $1.22+/-1.66$ & $p=0.001$ & 1 \\
\hline TNF- $\alpha$ & $0.00+/-0.00$ & $0.79+/-1.29$ & $p=0.006$ & 2.5 \\
\hline IFN- $\gamma$ & $0.00+/-0.00$ & $0.10+/-0.23 \mathrm{M}$ & $p=0.037$ & 1 \\
\hline
\end{tabular}

tients with ratio CD4/CD8 $<2$, had the levels of IL-10 to $1.87+/-1.62 \mathrm{pg} / \mathrm{ml}$ and $0.47+/-0.42 \mathrm{pg} / \mathrm{ml}$, respectively, $(p=0.031)$. All the other cytokines evaluated were either normal when compared to control group, or under the detection limits of relative ELISA kit. 


\subsection{Association between Cytokine Polymorphisms and Clinical Data}

The analysis of allele and genotype frequencies did not show significant differences when clinical data such as gender, age at onset, or other clinical complications collected during follow-up, were considered (data not shown).

Instead, the analysis of the clinical parameters collected before treatment, showed a significant correlation, but only between proteinuria and the polymorphism T-590C of IL-4. Indeed, the genotypes TT, CT and CC had levels of proteinuria to $4.92+/-2.09,3.74+/-1.31$ and $3.0+/-0.81 \mathrm{~g} /$ day, respectively, $(p=0.022)$, (Figure 1(a)).

For IL-4 T-33C, the proteinuria levels in TT, TC and CC were $4.75+/-0.63,3.88+/-1.62$ and $3.19+/-1.10$ g/day, respectively, ( $p=$ not significant), (Figure $1(b)$ ).

However, we did not observe other correlations between polymorphisms investigated and other parameters such as albumin levels, cholesterol levels or creatinine clearance (data not shown).

\section{Discussion}

In this study, we revealed the association between polymorphisms in IL-4 (T-590C, T-33C) and in TNF- $\alpha$ (G-308A) and the development of IMN syndrome. In addition, in a subgroup of patients with increased T-helper lymphocytes, an association is shown between IL-10 polymorphisms G-1082A and C-819T and the disease. Furthermore, we showed that the cytokine levels of IL-4 in serum and IL-5 and IL-10 in urine are often increased in IMN patients.

These data are in agreement with the hypothesis that IMN is a Th2 type immune-mediated pathology. Some authors already described that T-helper lymphocytes of patients affected by IMN have increased production of IL-4 [9] and B lymphocytes, stimulated with IL-4, generate more IgG4 compared to healthy individuals [10]. In the latter study, the authors showed the increased expression of IL-10 and IL-13 in PBMCs, as well as an increase in CD4/CD8 ratio in patients.

The increased CD4/CD8 ratio in IMN represents the altered immune response associated to the pathogenesis of the disease [10], [28]-[31]. We found that CD4/CD8 ratio was greater than two only in twenty four patients out of forty five. Nevertheless, in this subgroup, we observed the presence of two predominant polymorphisms of IL-10. IL-10 is one of the major Th2 cytokines, which acts on B lymphocytes stimulating the production of antibodies. In particular, this effect is further enhanced on B lymphocytes that are already IgG4 committed. In fact, in PBMCs stimulated with anti CD40 and IL-4, the addition of IL-10 increases IL-4 induced $\gamma 4$ transcription and IgG4 production [11]-[13]. The most frequent allele of IL-10 in group of patients with CD4/CD8 ratio more than two was -1082G, which is associated to the increased production of IL-10 [20] [32], in fact in this subgroup of patients the levels of IL-10, in the urine, were higher compared to patients with CD4/CD8 ratio less than two.

Therefore, in the group of patients with increased CD4/CD8 ratio, IL-10 can be related to the pathogenesis of IMN and it might represent a new insight in the pathogenesis of this disease, as well as its role has been shown in other kidney diseases [33].

Moreover, IL-10 is a strong anti-inflammatory cytokine, which down regulates the production of TNF- $\alpha$ and the activity of APCs [34]-[36]. IL-10, as for TNF- $\alpha$, is not only produced by Th2 lymphocytes but also by mo-

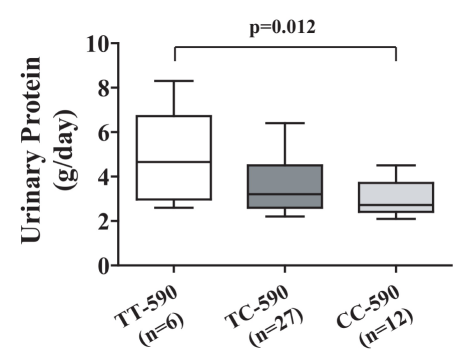

(a)

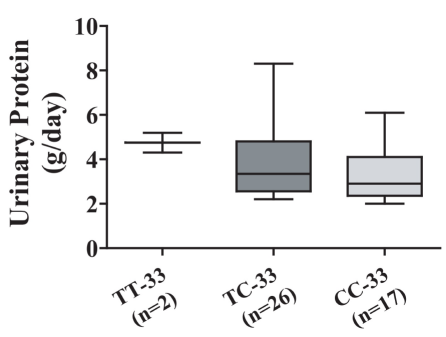

(b)

Figure 1. Boxplots of proteinuria levels by -590 and -33 IL-4 genotypes, in IMN patients. 
nocytes and macrophages. It has been observed that inflammatory cells recruited to glomerulus and the visceral epithelial cells produce TNF- $\alpha$ in IMN [37]. In a similar way, IL-10 can also be produced in loco by the inflammatory cells recruited to the damaged glomerulus. Therefore, the presence of IL-10 in urine, but not in serum, can be partly explained as an effect of inflammatory response triggered by the presence of TNF- $\alpha$. In agreement with this observation some authors described the presence of IL-10 in glomerular lesions, in patients affected with glomerulonephritis [38].

Likewise, IL-4 and IL-5 are both produced by Th2 lymphocytes. IL-4 is up regulated by peripheral T-helper cells in IMN [9], demonstrating its' systemic origin rather than produced in loco after glomerular damage. However in some cases, it has been demonstrated that there are increased mRNA levels of IL-4 and IL-5 in renal biopsies from MN patients, giving an evidence of local origin of these cytokines at the site of inflammation [39]. So, our results for the presence of IL-4 in serum are in agreement with Masutani et al. [9], while the presence of IL-5 in urine can be related to the immunological phenomena in glomerulus, as partly stated by Ifuku et al. [39] Nevertheless, these results confirm an injurious immune response due to T lymphocytes dysregulation in IMN pathogenesis.

The association between polymorphisms G-308A in TNF- $\alpha$ and IMN has already been described [25] [26]. Bantis C et al. [26] showed that the allele -308A was more frequent in patients affected by membranous glomerulonephritis. Likewise, the genotype distribution for genotypes GG, GA, and AA were also different. Similar results were shown by Tibaudin et al. [25] in IMN, where frequency of -308A allele was increased in patients. Nevertheless they did not suggest any significant and independent influence of different genotypes on diseases' progression. The increased levels of TNF- $\alpha$ in urine [40]-[42] and its expression in kidney cells [37] [40]-[42] of IMN affected patients, suggest a role of TNF- $\alpha$ in this syndrome. Hence, the presence of TNF- $\alpha$ together with IL-10 in urine emphasizes the significance of inflammatory processes and the role of TNF- $\alpha$ in the pathogenesis of IMN.

This role is more evident considering that the allele -308A of TNF- $\alpha$ is associated with a high expression of this cytokine [22]-[23]. TNF- $\alpha$ plays a role in the pathogenesis by contributing to the alterations of glomerular filtration barrier [43]. Besides, -308A allele of TNF- $\alpha$ is in linkage with HLA-B8/DR3 haplotype [44], which is also associated to the development of IMN [45]. Recent studies have further shown that TNF- $\alpha$ polymorphisms increase susceptibility to develop other forms of kidney disease [46].

The relevance of IL-4 (which is not in linkage disequilibrium with the MHC complex genes) and other Th2 cytokines is already described in the context of Minimal Change Nephrotic Syndrome, where the polymorphism T-590C of IL-4 [14] were more frequent in patients. Additionally, in some cases, the polymorphism T-590C of IL-4 is linked to the up regulation of this cytokine [19]. The potential role of this "high producer" genotype is also described in other Th2 mediated pathologies like atopic dermatitis, allergies and asthma. For example, our group described the association of T-590C polymorphism with asthma in the Italian population [27] and Kawashima et al. associated the same polymorphism with atopic dermatitis in the Japanese population [19].

Furthermore, we found an increase in two polymorphisms of IL-4 in our cohort of patients, namely T-590C and T-33C, moreover, we showed that T-590 allele is also associated with a proteinuria increment.

Moreover, we observed increased levels of IL-4 in serum of patients with IMN. This observation was in agreement with Masutani et al. [9] who described an increase of Th2 lymphocytes in peripheral blood of IMN patients. The key role of IL-4 might be the induction of isotype switching towards IgG4 [10], which is the main antibody subtype to accumulate in glomerular epithelium, causing the alterations and pathogenesis of this disease. The relevance of IL-4 has also been shown in other nephropathies. For example, Acharya B et al. described the association between minimal change nephrotic syndrome (MCNS) and C-590T polymorphism of IL-4 [14]. MCNS is the most common nephrotic syndrome in children and it is associated with proteinuria, hypogammaglobinemia, hypercholesterolemia and increased levels of IgE in serum. MCNS is also characterized by an aberrant immune response of $\mathrm{T}$ lymphocytes. Furthermore, factors derived from $\mathrm{T}$ cells are responsible for the alterations at glomerular barrier observed in this syndrome [47]-[50]. So, the same mechanisms can also be considered in the pathogenesis of IMN.

However, the association between the allele T-590 and the production of IL-4 remains questionable.

Li et al. have recently confirmed, through a study of meta-analysis, that the genotype -590TT is associated with an increase in the risk of developing allergic rhinitis. However, they have not shown a correlation between the serum level of IL-4 and allergic rhinitis [51]. While, Amirzargar et al. have shown that T-590 allele is associated with increased levels of IgE in vivo, as well as to the predisposition to asthma development [52]. The 
same correlation was observed in the cohort of asthmatic subjects by Smolnikova et al. In addition, here, the author shows that the T-590 allele of IL-4 is responsible for an increase in serum levels of IL-4 [53], confirming what we have observed in our group of patients.

\section{Conclusion}

In conclusion, our results suggest that polymorphisms in cytokine genes, mainly IL-4, IL-10 and TNF- $\alpha$ can be associated to IMN, suggesting that this pathology can be considered as a complex disease and that multiple mechanisms might be involved in its pathogenesis. Moreover, to our knowledge, this is the first study to associate IL-4 polymorphisms in Italian population to the Idiopathic Membranous Nephropathy.

\section{Acknowledgements}

We are grateful to the unit of Nephrology of Ospedali Riuniti of Bergamo for their contribution to this work.

\section{References}

[1] Nangaku, M., Shankland, S.J. and Couser, W.G. (2005) Cellular Response to Injury in Membranous Nephropathy. Journal of the American Society of Nephrology, 16, 1-9. http://dx.doi.org/10.1681/ASN.2004121098

[2] Imai, H., Hamai, K., Komatsuda, A., Ohtani, H. and Miura, A.B. (1997) IgG Subclasses in Patients with Membranoproliferative Glomerulonephritis, Membranous Nephrophaty, and Lupus Nephritis. Kidney International, 51, 270-276. http://dx.doi.org/10.1038/ki.1997.32

[3] Kuroki, A., Shibata, T., Honda, H., Totsuka, D., Kobayashi, K. and Sugisaki, T. (2002) Glomerular and Serum IgG Subclasses in Diffuse Proliferative Lupus Nephritis, Membranous Lupus Nephritis, and Idiophatic Membranous Nephrophaty. Internal Medicine, 41, 936-942. http://dx.doi.org/10.2169/internalmedicine.41.936

[4] Ohtani, H., Wakui, H., Komatsuda, A., Okuyama, S., Masai, R., Maki, N., Kigawa, A., Sawada, K. and Imai, H. (2004) Distribution of Glomerular IgG Sublcass Deposits in Malignancy-Associated Membranous Nephropathy. Nephrology Dialysis Transplantation, 19, 574-579. http://dx.doi.org/10.1093/ndt/gfg616

[5] Aalberse, R.C., Van der Gaag, R. and Van Leeuwen, J. (1983) Serologic Aspects of IgG4 Antibodies. I. Prolonged Immunization Results in an IgG4 Restricted Response. The Journal of Immunology, 130, 722-726.

[6] Iskander, R., Das, P.K. and Aalberse, R.C. (1981) IgG4 Antibodies in Egyptian Patients with Schistosomiasis. 'International Archives of Allergy and Immunology, 66, 200-207. http://dx.doi.org/10.1159/000232819

[7] Doi, T., Kanatsu, K., Mayumi, M., Hamashima, Y. and Yoshida, H. (1991) Analysis of IgG Immune Complexes in Sera from Patients with Membranous Nephropathy: Role of IgG4 Subclass and Low-Avidity Antibodies. Nephron, 57, 131-136. http://dx.doi.org/10.1159/000186239

[8] van de Zee, J.S., van Swieten, P. and Aalberse, R.C. (1986) Serologic Aspects of IgG4 Antibodies. II. IgG4 Antibodies Form Small, Nonprecipitating Immune Complexes Due to Functional Monovalency. The Journal of Immunology, 137, 3566-3571.

[9] Masutani, K., Taniguchi, M., Nakashima, H., Yotsueda, H., Kudoh, Y., Tsuruya, K., Tokumoto, M., Fukuda, K., Kanai, H., Hirakata, H. and Iida, M. (2004) Up-Regulated Interleukin-4 Production by Peripheral T-Helper Cells in Idiopathic Membranous Nephrophaty. Nephrology Dialysis Transplantation, 19, 580-586. http://dx.doi.org/10.1093/ndt/gfg572

[10] Kuroki, A., Iyoda, M., Shibata, T. and Sugisaki, T. (2005) Th2 Cytokines Increase and Stimulate B Cells to Produce IgG4 in Idiopathic Membranous Nephropathy. Kidney International, 68, 302-310. http://dx.doi.org/10.1111/j.1523-1755.2005.00415.X

[11] Jeannin, P., Lecoanet, S., Delneste, Y., Gauchat, J.F. and Bonnefoy, J.Y. (1998) IgE versus IgG4 Production Can Be Differentially Regulated by IL-10. Journal of Immunology, 160, 3555-3561.

[12] de Vries, J.E., Punnonen, J., Cocks, B.G. and Aversa, G. (1993) The Role of T/B Cell Interactions and Cytokines in the Regulation of Human IgE Synthesis. Seminars in Immunology, 5, 431-439. http://dx.doi.org/10.1006/smim.1993.1049

[13] Lecart, S., Morel, F., Noraz, N., Pène, J., Garcia, M., Boniface, K., Lecron, J.C. and Yssel, H. (2002) IL-22, in Contrast to IL-10, Does Not Induce Ig Production, Due to Absence of a Functional IL-22 Receptor on Activated Human B Cells. International Immunology, 14, 1351-1356. http://dx.doi.org/10.1093/intimm/dxf096

[14] Acharya, B., Shirakawa, T. and Gotoh, A. (2005) Polymorphism of the Interleukin-4, Interleukin-13, and Signal Trasducer and Activator of Transcription 6 Genes in Indonesian Children with Minimal Change Nephrotic Syndrome. American Journal of Nephrology, 25, 30-35. http://dx.doi.org/10.1159/000083729

[15] Ikeuchi, Y., Kobayashi, Y., Arakawa, H., Suzuki, M., Tamra, K. and Morikawa, A. (2009) Polymorphisms in Interleu- 
kin-4-Related Genes in Patients with Minimal Change Nephrotic Syndrome. Pediatric Nephrology, 24, 489-495. http://dx.doi.org/10.1007/s00467-008-1003-y

[16] Cohen, C.D., Calvaresi, N. and Kretzler, M. (2005) CD20-Positive Infiltrates in Human Membranous Glomerulonephritis. Journal of Nephrology, 18, 328-333.

[17] Ruggenenti, P., Chiurchiu, C., Abbate, M., Perna, A., Cravedi, P., Bontempelli, M. and Remuzzi, G. (2006) Rituximab for Idiopathic Membranous Nephropathy: Who Can Benefit? Clinical Journal of the American Society of Nephrology, 1, 738-748. http://dx.doi.org/10.2215/CJN.01080905

[18] Remuzzi, G., Chiurchiu, C., Abbate, M., Brusegan, V., Bontempelli, M. and Ruggenenti, P. (2002) Rituximab for Idiopathic Membranous Nephropathy. The Lancet, 360, 923-924. http://dx.doi.org/10.1016/S0140-6736(02)11042-7

[19] Kawashima, T., Noguchi, E., Arinami, T., Yamakawa-Kobayashi, K., Nakagawa, H., Otsuka, F. and Hamaguchi, H. (1998) Linkage and Association of an Interleukin-4 Gene Polymorphism with Atopic Dermatitis in Japanese Families. Journal of Medical Genetics, 35, 502-504. http://dx.doi.org/10.1136/jmg.35.6.502

[20] Turner, D.M., Williams, D.M., Sankaran, D., Lazarus, M., Sinnott, P.J. and Hutchinson, I.V. (1997) An Investigation of Polymorphism in the Interleukin-10 Gene Promoter. European Journal of Immunogenetics, 24, 1-8. http://dx.doi.org/10.1111/j.1365-2370.1997.tb00001.x

[21] Kim, J.M., Brannan, C.I., Copeland, N.G., Jenkins, N.A., Khan, T.A. and Moore, K.W. (1992) Structure of the Mouse IL-10 Gene and Chromosomal Localization of the Mouse and Human Genes. Journal of Immunology, 148, 3618-3623.

[22] Louis, E., Franchimont, D., Piron, A., Gevaert, Y., Schaaf-Lafontaine, N., Roland, S., Mahieu, P., Malaise, M., De Groote, D., Louis, R. and Belaiche, J. (1998) Tumour Necrosis Factor (TNF) Gene Polymorphism Influences TNF- $\alpha$ Production in Lipopolysaccharide (LPS)-Stimulated Whole Blood Cell Culture in Healthy Humans. Clinical and Experimental Immunology, 113, 401-406. http://dx.doi.org/10.1046/j.1365-2249.1998.00662.X

[23] Wilson, A.G., Symons, J.A., McDowell, T.L., McDevitt, H.O. and Duff, G.W. (1997) Effects of a Polymorphisms in the Human Tumour Necrosis Factor $\alpha$ Promoter on Transcriptional Activation. Proceedings of the National Academy of Sciences of the United States of America, 94, 3195-3199. http://dx.doi.org/10.1073/pnas.94.7.3195

[24] Chen, S.Y., Chen, C.H., Huang, Y.C., Chuang, H.M., Lo, M.M. and Tsai, F.J. (2010) Effect of IL-6 C-572G Polymorphism on Idiopathic Membranous Nephropathy Risk in a Han Chinese Population. Renal Failure, 32, 1172-1176. http://dx.doi.org/10.3109/0886022X.2010.516857

[25] Thibaudin, D., Thibaudin, L., Berthoux, P., Mariat, C., Filippis, J.P., Laurent, B., Alamartine, E. and Berthoux, F. (2007) TNFA2 and D2 Alleles of the Tumor Necrosis Factor Alpha Gene Polymorphism Are Associated with Onset/ Occurrence of Idiopathic Membranous Nephropathy. Kidney International, 71, 431-437. http://dx.doi.org/10.1038/sj.ki.5002054

[26] Bantis, C., Heering, P.J., Aker, S., Siekierka, M., Kuhr, N., Grabensee, B. and Ivens, K. (2006) Tumor Necrosis Factor- $\alpha$ Gene G-308A Polymorphism Is a Risk Factor for the Development of Membranous Glomerulonephritis. American Journal of Nephrology, 26, 12-15. http://dx.doi.org/10.1159/000090706

[27] Ricciardolo, F.L., Sorbello, V., Silvestri, M., Giacomelli, M., Debenedetti, V.M., Malerba, M., Ciprandi, G., Rossi, G.A., Rossi, A. and Bontempelli, M. (2013) TNF- $\alpha$, IL-4R- $\alpha$ and IL-4 Polymorphisms in Mild to Severe Asthma from Italian Caucasians. International Journal of Immunopathology and Pharmacology, 26, 75-84.

[28] Ozaki, T., Tomino, Y., Nakayama, S. and Koide, H. (1992) Two-Color Analysis of Lymphocyte Subpopulations in Patients with Nephrotic Syndrome Due to Membranous Nephropathy. Clinical Nephrology, 38, 75-80.

[29] Zucchelli, P., Ponticelli, C., Cagnoli, L., Aroldi, A. and Beltrandi, E. (1988) Prognostic Value of T Lymphocyte Subset Ratio in Idiopathic Membranous Nephropathy. American Journal of Nephrology, 8, 15-20. http://dx.doi.org/10.1159/000167547

[30] Cagnoli, L., Tabacchi, P., Pasquali, S., Cenci, M., Sasdelli, M. and Zucchelli, P. (1982) T Cell Subset Alterations in Idiopathic Glomerulonephritis. Clinical \& Experimental Immunology, 50, 70-76.

[31] Bannister, K.M., Drew, P.A., Clarkson, A.R. and Woodroffe, A.J. (1983) Immunoregulation in Glomerulonephritis, Henoch-Schonlein Purpura and Lupus Nephritis. Clinical \& Experimental Immunology, 53, 384-390.

[32] Castro-Santos, P., Suarez, A., López-Rivas, L., Mozo, L. and Gutierrez, C. (2006) TNF $\alpha$ and IL-10 Gene Poly-morphisms in Inflammatory Bowel Disease. Association of -1082 AA Low Producer IL-10 Genotype with Steroid Dependency TNF $\alpha$ and IL-10 Gene Polymorphisms in IBD. American Journal of Gastroenterology, 101, 1039-1047. http://dx.doi.org/10.1111/j.1572-0241.2006.00501.x

[33] Rianthavorn, P., Chokedeemeeboon, C., Deekajorndech, T. and Suphapeetiporn, K. (2013) Interleukin-10 Promoter Polymorphisms and Expression in Thai Children with Juvenile Systemic Lupus Erythematosus. Lupus, 22, 721-726. http://dx.doi.org/10.1177/0961203313486192

[34] Fiorentino, D.F., Zlotnik, A., Mosmann, T.R., Howard, M. and O’Garra, A. (1991) IL-10 Inhibits Cytokine Production by Activated Macrophages. Journal of Immunology, 147, 3815-3822. 
[35] de Waal Malefyt, R., Abrams, J., Bennett, B., Figdor, C.G. and de Vries, J.E. (1991) Interleukin 10 (IL-10) Inhibits Cytokine Synthesis by Human Monocytes: An Autoregulatory Role of IL-10 Produced by Monocytes. Journal of Experimental Medicine, 174, 1209-1220. http://dx.doi.org/10.1084/jem.174.5.1209

[36] de Waal Malefyt, R., Haanen, J., Spits, H., Roncarolo, M.G., te Velde, A., Figdor, C., Johnson, K., Kastelein, R., Yssel, H. and de Vries, J.E. (1991) Interleukin 10 (IL-10) and Viral IL-10 Strongly Reduce Antigen-Specific Human T Cell Proliferation by Diminishing the Antigen-Presenting Capacity of Monocytes via Downregulation of Class II Major Histocompatibility Complex Expression. Journal of Experimental Medicine, 174, 915-924. http://dx.doi.org/10.1084/jem.174.4.915

[37] Neale, T.J., Rüger, B.M., Macaulay, H., Dunbar, P.R., Hasan, Q., Bourke, A., Murray-McIntosh, R.P. and Kitching, A.R. (1995) Tumor Necrosis Factor- $\alpha$ Is Expressed by Glomerular Visceral Epithelial Cells in Human Membranous Nephropathy. American Journal of Pathology, 146, 1444-1454.

[38] Niemir, Z.I., Ondracek, M., Dworacki, G., Stein, H., Waldherr, R., Ritz, E. and Otto, H.F. (1998) In Situ Upregulation of IL-10 Reflects the Activity of Human Glomerulonephritides. American Journal of Kidney Diseases, 32, 80-92. http://dx.doi.org/10.1053/ajkd.1998.v32.pm9669428

[39] Ifuku, M., Miyake, K., Watanebe, M., Ito, K., Abe, Y., Sasatomi, Y., Ogahara, S., Hisano, S., Sato, H., Saito, T. and Nakashima, H. (2013) Various Roles of Th Cytokine mRNA Expression in Different Forms of Glomerulonephritis. American Journal of Nephrology, 38, 115-123. http://dx.doi.org/10.1159/000353102

[40] Honkanen, E., von Willebrand, E., Teppo, A.M., Törnroth, T. and Grönhagen-Riska, C. (1998) Adhesion Molecules and Urinary Tumor Necrosis Factor- $\alpha$ in Idiopathic Membranous Glomerulonephritis. Kidney International, 53, 909917. http://dx.doi.org/10.1111/j.1523-1755.1998.00833.x

[41] Kshirsagar, A.V., Nachman, P.H. and Falk, R.J. (2003) Alternative Therapies and Future Intervention for Treatment of Membranous Nephropathy. Seminars in Nephrology, 23, 362-372. http://dx.doi.org/10.1016/S0270-9295(03)00047-0

[42] Wu, T.H., Tsai, C.Y. and Yang, W.C. (1998) Excessive Expression of the Tumor Necrosis Factor- $\alpha$ Gene in the Kidneys of Patients with Membranous Glomerulonephritis. Chinese Medical Journal (Taipei), 61, 524-530.

[43] Tabibzadeh, S., Kong, Q.F., Kapur, S., Leffers, H., Ridley, A., Aktories, K. and Celis, J.E. (1995) TNF- $\alpha$ Induces Dyscohesion of Epithelial Cells. Association with Disassembly of Actin Filaments. Endocrine, 3, 549-556. http://dx.doi.org/10.1007/BF02953018

[44] Wilson, A.G., de Vries, N., Pociot, F., di Giovine, F.S., van der Putte, L.B. and Duff, G.W. (1993) An Allelic Polymorphism within the Human Tumor Necrosis Factor Alpha Promoter Region Is Strongly Associated with HLA A1, B8, and DR3 Alleles. Journal of Experimental Medicine, 177, 557-560. http://dx.doi.org/10.1084/jem.177.2.557

[45] Reichert, L.J., Koene, R.A. and Wetzels, J.F. (1998) Prognostic Factors in Idiopathic Membranous Nephropathy. American Journal of Kidney Diseases, 31, 1-11. http://dx.doi.org/10.1053/ajkd.1998.v31.pm9428445

[46] Farid, T.M., Abd El Baky, A.M., Khalefa, E.S., Talaat, A.A., Mohamed, A.A., Gheita, T.A. and Abdel-Salam, R.F. (2011) Association of Tumor Necrosis Factor- $\alpha$ Gene Polymorphisms with Juvenile Systemic Lupus Erythematosus Nephritis in a Cohort of Egyptian Patients. Iranian Journal of Kidney Diseases, 5, 392-397.

[47] Tomizawa, S., Maruyama, K., Nagasawa, N., Suzuki, S. and Kuroume, T. (1985) Studies on Vascular Permeability Factor Derived from T Lymphocytes and Inhibitory Effect of Plasma on Its Production in Minimal Change Nephrotic Syndrome. Nephron, 41, 157-160. http://dx.doi.org/10.1159/000183572

[48] Cho, B.S., Yoon, S.R., Jang, J.Y., Pyun, K.H. and Lee, C.E. (1999) Up-Regulation of Interleukin-4 and CD23/ FcepsilonRII in Minimal Change Nephrotic Syndrome. Pediatric Nephrology, 13, 199-204. http://dx.doi.org/10.1007/s004670050592

[49] Neuhaus, T.J., Shah, V., Callard, R.E. and Barratt, T.M. (1995) T-Lymphocyte Activation in Steroid-Sensitive Nephrotic Syndrome in Childhood. Nephrology Dialysis Transplantation, 10, 1348-1352.

[50] Neuhaus, T.J., Wadhwa, M., Callard, R. and Barratt, T.M. (1995) Increased IL-2, IL-4 and Interferon-Gamma (IFNGamma) in Steroid-Sensitive Nephrotic Syndrome. Clinical \& Experimental Immunology, 100, 475-479. http://dx.doi.org/10.1111/j.1365-2249.1995.tb03725.X

[51] Li, Z.P., Yin, L.L., Wang, H. and Liu, L.S. (2014) Association between Promoter Polymorphisms of Interleukin-4 Gene and Allergic Rhinitis Risk: A Meta-Analysis. Journal of Huazhong University of Science and Technology (Medical Sciences), 34, 306-313. http://dx.doi.org/10.1007/s11596-014-1275-3

[52] Amirzargar, A.A., Movahedi, M., Rezaei, N., Moradi, B., Dorkhosh, S., Mahloji, M. and Mahdaviani, S.A. (2009) Polymorphisms in IL4 and iLARA Confer Susceptibility to Asthma. Journal of Investigational Allergology and Clinical Immunology, 19, 433-438.

[53] Smolnikova, M.V., Smirnova, S.V., Freidin, M.B. and Tyutina, O.S. (2013) Immunological Parameters and Gene Polymorphisms (C-590T IL4, C-597A IL10) in Severe Bronchial Asthma in Children from the Krasnoyarsk Region, West Siberia. International Journal of Circumpolar Health, 72. http://dx.doi.org/10.3402/ijch.v72i0.21159 